\title{
WIZJA EUROPY ŚRODKOWOWSCHODNIEJ W PROJEKTACH GEOPOLITYCZNYCH IDEOLOGA EURAZJATYZMU, ALEKSANDRA DUGINA
}

\author{
КАРТИНА ЦЕНТРАЛЬНОЙ И ВОСТОЧНОЙ ЕВРОПЫ \\ В ГЕОПОЛИТИЧЕСКИХ ПРОЕКТАХ ИДЕОЛОГА \\ ЕВРАЗИЙСТВА АЛЕКСАНДРА ДУГИНА
}

\section{VISION OF THE EAST-CENTRAL EUROPE \\ IN GEOPOLITICAL PROJECT OF IDEOLOGIST EURASIANISM ALEKSANDR DUGIN}

\author{
Maciej Bala \\ Uniwersytet im. A. Mickiewicza w Poznaniu, Poznań - Polska
}

\begin{abstract}
The article is an attempt to present the views of the Russian thinker on the political situation in the post-Soviet region. In his conception Aleksandr Dugin focuses on geopolitics, international relations and the position of Russia in the new globalised world. Dugin attempts to undermine the principles of the new world order. He creates ideological foundations which may serve as a justification for regaining the imperial position of Russia. The foundation of Dugin's views is Eurasianism combined with the elements of geopolitics. The philosopher creates a blueprint for the Great Eurasian Empire which would comprise East-Central Europe. According to Dugin, significant political and territorial changes will be conducted in this region on the basis of the religious faith of its inhabitants. The protestant countries will be federalized. Both the Protestant and Catholic countries will become the Germany's sphere of influence. The Balkan states will have a somewhat different status as they will be federalized into one political subject connected with Eurasia. Germany and Russia, whose position is dominant in this region of Europe, will become a part of the Great Eurasian Empire. There will be no room left for independent Poland and Ukraine in the structure of the Eurasian Empire. Dugin does not take into account economic factors which would convince European states to integrate with Eurasia. As for the present day, it is impossible to put the Eurasian project into realization.
\end{abstract}

Słowa kluczowe: eurazjatyzm, Aleksander Dugin, Europa Środkowowschodnia Ключевые слова: Евразийство, Александр Дугин, Центральная и Восточная Европа Keywords: Eurasianism, Aleksandr Dugin, Central and Eastern Europe

Rozpad Związku Radzieckiego w 1991 roku przypieczętował bankructwo ideologii komunistycznej oraz całkowicie zmienił znaczenie Rosji na arenie międzynarodowej. Przebieg procesu degradacji sowieckie- 
go imperium i szybkość, z jaką nastąpił jego upadek, został przez społeczność międzynarodową przyjęty ze zdumieniem i niedowierzaniem. Niedługo po tym, jak ideologia komunistyczna przestała być alternatywną wobec demokracji, wysunięto tezę zakładającą nieuniknione zwycięstwo tej drugiej i upowszechnieniu się jej we wszystkich panstwach świata1. Okazało się jednak, że zniknięcie ideologii komunistycznej nie oznaczało nieuchronnego triumfu demokracji na świecie i przyjęcia jej przez wszystkie państwa zachodniej kultury. W miejsce ideologii komunistycznej szybko pojawił się nacjonalizm oraz fundamentalizm religijny².

Rosja postkomunistyczna od 2000 roku rządzona przez Władimira Putina, przez długi czas nie powoływała się na żadną konkretną ideologię, która mogłaby zastąpić zdyskredytowaną ideologię komunistyczną. Z czasem jednak wśród wielu polityków rosyjskich coraz większą popularność zdobywał specyficzny prąd filozoficzny zwany eurazjatyzmem. Prąd ten nie był niczym nowym, powstał bowiem już w okresie międzywojennym w kręgach rosyjskiej emigracji. Grupa zwolenników eurazjatyzmu, skupiona wokół hrabiego Nikołaja Trubieckiego, początkowo nie miała charakteru politycznego, $\mathrm{w}$ większym stopniu skupiała się na zagadnieniach kulturowych oraz językoznawczych. W późniejszym okresie działalności, eurazjaci zaczęli formułować hasła polityczne, co wywołało spory i w końcu lat 30 . doprowadziło do rozpadu grupy ${ }^{3}$. Ich myśl, już na gruncie rosyjskim, kontynuował Lew Nikołajewicz Gumilow, koncentrując się na zagadnieniach historycznych i etnicznych. W swoich pracach, skupiał się na kwestii kontaktów między etnosami i możliwych tego konsekwencji, podkreślał odrębność kulturową Rosji i szkodliwy wpływ, jaki, w jego mniemaniu, wywiera na nią Zachód. Po śmierci Lwa Gumilowa w roku 1992, kwestię ideologii eurazjatyckiej podjął kontrowersyjny filozof Aleksander Gielewicz Dugin.

Eurazjatyzm we współczesnej Rosji, znacząco różni się od dwóch poprzednich, podejmuje bowiem, obok zagadnień kulturowych i językowych, również kwestie religijne, metafizyczne, cywilizacyjne i przede wszystkim geopolityczne.

Aleksander Dugin jest znany jako filozof, ale przede wszystkim zajmuje się kwestiami geopolitycznymi. Ma szeroki zakres zainteresowań,

${ }^{1}$ Tego typu tezę wysunął Francis Fukuyama, jednakże niedługo potem wycofał się z niej. Porównaj: F. Fukuyama, Koniec historii, Kraków 2009.

${ }^{2}$ Zwraca na to uwagę amerykański politolog Samuel Huntington. Wysunął on tezę, w której zakładał, iż najwięcej konfliktów międzynarodowych będzie przebiegało na tle cywilizacyjnym. Dana teza pomimo niedoskonałości warta jest zapoznania się. Patrz w: S. Huntington, Zderzenie cywilizacji, Warszawa 2005.

${ }^{3}$ Więcej na temat międzywojennego eurazjatyzmu, patrz: R. Backer, Międzywojenny eurazjatyzm: od intelektualnej kontr akulturacji do totalitaryzmu?, Łódź 2000. 
w swoich pracach nawiązuje do myśli tzw. Nowej Prawicy, prawosławia, ezoteryki i okultyzmu.

Zainteresowanie okultyzmem i alternatywnymi prądami religijnymi wykazywał już w czasie studiów. Od 1980 roku przynależał do grupy skupionej wokół gnostyka Jurija Mamlejewa ${ }^{4}$. Później dołączył do ugrupowania Jewgienija Gołowina. Miało ono charakter okultystyczny i ariozoficzny. Był również członkiem Narodowo-Patriotycznego Frontu „Pamięć" Dmitrija Wasiljewa, z którego usunięto go pod zarzutem satanizmu ${ }^{5}$. Na początku lat 90. redagował gazetę "День" i „Завтора", a także almanach "Милый Ангел”. Pod koniec lat 80. założył filozoficzne centrum "EON”, przekształcone później w stowarzyszenie "Arctogeia”. W latach 1993-1998 współpracował z pisarzem Eduardem Limonowem, będąc jednym z dwóch "ojców założycieli" Partii Narodowo-Bolszewickiej. Z niewyjaśnionych do dziś powodów ${ }^{6}$, zerwał współpracę z kontrowersyjnym pisarzem. W roku 2001 utworzył Ogólnorosyjski Polityczny Ruch Społeczny „Eurazja”. Sama zaś partia „Eurazja” formalnie powstała 30 maja 2002 roku$^{7}$ (od 2003 roku funkcjonuje jako Międzynarodowy Ruch Eurazjatycki), ale nie odniosła dotąd znaczących sukcesów na rosyjskiej scenie politycznej. Obok niej funkcjonuje Eurazjatycki Sojusz Młodzieży, utworzony w lutym 2005 roku. Pomimo niepowodzeń własnego ugrupowania, Aleksander Dugin w latach 1998-2003 pełnił funkcję doradcy przewodniczącego rosyjskiej Dumy Państwowej Giennadija Selezniowa. Po nieudanej próbie wzięcia udziału w wyborach parlamentarnych w 2003 roku, Dugin skupia się na uważnym obserwowaniu i komentowaniu rosyjskiej sceny politycznej. Obok funkcji lidera Międzynarodowego Ruchu Eurazjatyckiego, pełni również funkcję przewodniczącego stowarzyszenia "Arctogaia", prowadzi także własne audycje telewizyjne w nacjonalistycznym kanale "Спас", komentując w nich bieżące wydarzenia polityczne.

Aleksander Dugin w swoich publikacjach koncentruje się na zagadnieniach polityki międzynarodowej, objaśniając je w kategoriach swoiście przez niego pojmowanej geopolityki. Sam termin "geopolityka" oznacza:

4 P. J. Sieradzan, Aksamitni terroryści. Narodowy bolszewizm w Federacji Rosyjskiej, Warszawa 2008, s. 53.

${ }^{5}$ Ibidem, s. 54.

${ }^{6} \mathrm{Na}$ dzień dzisiejszy nie dysponujemy publikacjami Dugina na temat jego działalności w Partii Narodowo-Bolszewickiej i przyczyn jego rezygnacji. Informacje na temat motywów jego decyzji i ewentualnych przyczyn jego rezygnacji znaleźć możemy w książkach jego dawnego współpracownika Eduarda Limonowa. Patrz: Э. Лимонов, Анатомия героя, a także, idem, Моя политическая биография, [w:] źródło elektroniczne: www.limonow.de (01.10.2013).

${ }^{7}$ B. Gołąbek, Lew Gumilow i Aleksander Dugin. O dwóch obliczach eurazjatyzmu w Rosji po 1991 roku, Kraków 2012, s. 116. 
teorię głoszącą, iż polityka zewnętrzna i wewnętrzna państwa jest określana przez jego położenie geograficzne, otoczenie międzynarodowe. Jest to próba połączenia geografii i polityki ${ }^{8}$.

Zasadniczą koncepcją geopolityki w rozumieniu Aleksandra Dugina jest powoływanie się na archetypiczny konflikt między cywilizacją Lądu, a cywilizacją Morza, jednocześnie nadając owej konfrontacji charakter mistyczny. Być może Dugin nieświadomie inspiruje się koncepcją niemieckiego geostratega Karla Schmidta, który określał wymienione typy cywilizacji mianem Behemota i Lewiatana9. Zdaniem Dugina konflikt ten trwa od czasów starożytnych, aż po czasy dzisiejsze. Pod mianem cywilizacji Lądu (tellurokracji) filozof rozumie Rosjęㄹ, państwa środkowoazjatyckie, Indie, państwa arabskie. Jego zdaniem, cywilizacja Lądu jest skoncentrowana na poszanowaniu tradycji i rozwijaniu duchowości oraz podkreślaniu roli kolektywu oraz pracy. Jej przeciwieństwem, jest cywilizacja Morza (thalassokracja) utożsamiana z krajami Europy Zachodniej i przede wszystkim z jedynym supermocarstwem - Stanami Zjednoczonymi ${ }^{11}$, wraz z jej sojusznikami i instytucjami międzynarodowymi, będącymi pod jej dominującym wpływem. Charakterystycznymi cechami cywilizacji atlantyckiej, według Dugina, jest nacisk na indywidualizm, zaniedbanie sfery duchowej, kult pieniądza i materializmu oraz zmuszanie pozostałych państw do przyjęcia zachodnich rozwiązań politycznych, kultury i światopoglądu. Dla eurazjaty jest to dążeniem przez cywilizacje Morza do absolutnej hegemonii nad światem oraz zepchnięcie Rosji do pozycji drugorzędnej na arenie międzynarodowej.

W celu przeciwdziałania, według określenia Dugina, próbom narzucenia hegemonii atlantyzmu, konieczne jest stworzenie wielkiego imperium eurazjatyckiego (jego obszar pokrywałby się z terytorium dawnego ZSRR, a najważniejszą częścią pozostałaby Rosja) zdolnego przeciwdziałać próbom, sprzymierzonego $\mathrm{z}$ państwami pozostającymi w napiętych

${ }^{8} \mathrm{Cz}$. Mojsiejewicz, Leksykon wspótczesnych międzynarodowych stosunków politycznych, Wrocław 2004, s. 128-129. Jak podkreślają autorzy leksykonu, geopolityka nie jest dominantą w stosunkach międzynarodowych, ale nie należy pomijać wpływu czynników geograficznych na politykę.

${ }^{9}$ А. Дугин, Основы геополитики, [w:] źródło elektroniczne: www.arctogaia.ru (12.11.2013). Warto również dodać, iż w koncepcji geostrategicznej eurazjaty, prawdziwa suwerenność przynależy wyłącznie imperiom, nie zaś państwom. Porównaj: R. Backer, Rosyjskie myślenie polityczne za czasów prezydenta Putina, Toruń 2007, s. 200.

${ }^{10}$ Jak słusznie zauważa Bartosz Gołąbek Rosja w swojej historii, nie była wyłącznie mocarstwem lądowym, ale również morskim. Więcej na ten temat patrz: B. Gołąbek, Lew Gumilow i Aleksander Dugin..., op. cit., s. 132.

${ }^{11}$ Więcej na temat stosunków amerykańsko-rosyjskich, patrz: A. Bryc, Rosja w XXI wieku. Gracz światowy czy koniec gry?, Warszawa 2009. 
stosunkach ze Stanami Zjednoczonymi. Owe sojusze będą się koncentrować wokół trzech osi: Moskwa-Berlin. Moskwa-Teheran oraz MoskwaTokio ${ }^{12}$. Ze względu na obszerność danego zagadnienia ograniczymy się do analizy pierwszej z wymienionych osi Moskwa-Berlin i jej ewentualnych konsekwencji dla państw obszaru Europy Środkowowschodniej.

Stworzenie osi Moskwa-Berlin, zachodniego wektora imperium eurazjatyckiego, jak twierdzi eurazjata, pozwoli narodom środkowoeuropejskim wyzwolić się od "ucisku” konsumpcjonistycznej i rynkowej cywilizacji atlantyzmu oraz umożliwi wskrzeszenie ich narodowej woli, a także uczyni je samodzielnymi podmiotami stosunków międzynarodowych. Ich samodzielność będzie zapewniona całościowym potencjałem geopolitycznym Eurazji. Dugin zaznacza przy tym, iż dany sojusz będzie bardzo korzystny i dla Rosji, i dla Niemiec. Rosja uzyska łatwiejszy dostęp do nowoczesnych technologii i inwestycji, a Niemcy uzyskają geopolityczną niezależność od Stanów Zjednoczonych oraz dostęp do bogatych złóż surowców.

Obszar środkowoeuropejski $\mathrm{w}$ ramach sojuszy powinien być skupiony wokół Niemiec jako najbardziej wpływowego państwa w regionie, przy czym, jak zaznacza Dugin, Niemcy powinny unikać lekceważenia pozostałych państw, a traktować je jako potencjalnych partnerów politycznych i odnosić się z szacunkiem do ich kultury. Pomimo zapewnień Aleksandra Dugina o zachowaniu równorzędnej pozycji państw środkowoeuropejskich, po dalszym zapoznaniu się z jego projektami geopolitycznymi trudno $\mathrm{w}$ to uwierzyć.

Na początku postaramy się $\mathrm{w}$ przybliżeniu nakreślić plan nowego porządku politycznego na przestrzeni rozciągającej się od Finlandii i państw nadbałtyckich poprzez Polskę, Białoruś i Ukrainę, do państw bałkańskich. Najwięcej miejsca poświęcimy analizie kwestii polskiej i ukraińskiej.

Teren Europy Środkowowschodniej jako całość, zgodnie z koncepcjami geopolityki eurazjatyzmu, powinien być skupiony wokół Niemiec, a te $\mathrm{z}$ kolei winny być częścią imperium eurazjatyckiego. W celu wzmoc-

12 Projekty ewentualnych sojuszy imperium eurazjatyckiego zmieniały się w czasie. W opublikowanej w 1997 roku przez Dugina pozycji Основы геополитики opisane zostały wymienione wyżej sojusze. Porównaj: A. Dugin, Основы геополитики, [w:] źródło elektroniczne: www.arctogaia.ru (02.10.2013). Jednakże później, w Programie Międzynarodowego Ruchy Eurazjatyckiego, geopolityk nie wymieniał już osi Moskwa-Berlin, ale Moskwa-Delhi. Por.: Пpoграмма Международного „Евразийского движения”, [w:] źródło elektroniczne: www.evrazia. info (07.10.2013). Możliwe, że jest to związane z przemianami politycznymi w Europie Środkowej po roku 2004, kiedy to kilka państw danego regionu w tym Polska wstąpiły do Unii Europejskiej. Pomimo tego, ze względu na położenie Polski i Ukrainy pomiędzy Niemcami a Rosją, zdecydowaliśmy się szerzej przedstawić dane zagadnienie. 
nienia przymierza Niemiec i Rosji, Dugin proponuje przywrócenie na mapie Europy Prus. Oznaczałoby to przekazanie terytorium dzisiejszego Obwodu Kaliningradzkiego pod jurysdykcję Niemiec ${ }^{13}$. Wokół nowoutworzonych Prus, będących powiązanych z Niemcami, będzie skupiony blok państw skandynawskich i nadbałtyckich. Spoiwem danych państw wchodzących w skład bloku, według eurazjaty, będzie wyznanie protestanckie, wspólne im wszystkim i sprzyjające dobrym stosunkom między nimi. Dla eurazjaty, konieczne jest wyjście owych państw z Sojuszu Północnoatlantyckiego, a w konsekwencji przyszłe imperium eurazjatyckie przejmie nad nimi kontrolę strategiczną. Jedyną przeszkodą w rozwoju strategicznego bloku może stać się Litwa, ze względu na przewagę wyznania rzymskokatolickiego wśród ludności tego państwa. Zdaniem Dugina, częściowym rozwiązaniem danego problemu będzie wzmacnianie stabilności bloku protestanckiego i popieranie przeciwnych katolicyzmowi ruchów politycznych i religijnych.

Co do państw bałkańskich, dokładniej Serbii, Grecji, Bułgarii, filozof również proponuje stworzenie bloku państw, będącego w politycznym przymierzu z eurazjatyckim imperium. Serbia i Bułgaria, w przekonaniu Dugina, stanowią „eurazjatycki impuls”14 sprzyjający stworzeniu Federacji Bałkańskiej przychylnej eurazjatyckiemu imperium. Nie bez znaczenia jest czynnik religijny, przeważającym bowiem wyznaniem $\mathrm{w}$ danych państwach jest prawosławie, co stwarza pewną nić porozumienia między nimi a Rosją, wzmacniając eurazjatyckie wpływy na terytorium bałkańskim. Sama zaś Serbia jest nazywana przez eurazjatę forpocztą Eurazji ${ }^{15}$. W skład Federacji Bałkańskiej powinna przynależeć również Rumunia i Mołdawia, ale jako jedno państwo. Zjednoczona z Mołdawią Rumunia powinna być otoczona przez, pozostające $w$ sferze wpływów Eurazji, państwa prawosławne życzliwe wobec Niemiec.

W kwestii pozostałych państw, nie opisanych wyżej, w szczególności Czech, Słowacji, Węgier, Chorwacji, Słowenii, eurazjata podkreśla ich etniczną i religijną odmienność względem państw prawosławnych. Rosja, według ideologa, nie powinna obejmować owych państw swoją kontrolą, ale zaliczyć je do strefy wpływów Niemiec, które pozostają $\mathrm{w}$ ścisłym sojuszu z Eurazją. Jednakże imperium z przyczyn strategicznych zachowuje prawo do swojej obecności, na zachodnich krańcach Europy Środkowowschodniej.

${ }^{13}$ Jak uzasadnia eurazjata służyłoby to wzmocnieniu sojuszu między Moskwą a Berlinem poprzez usunięcie ostatniego świadectwa bratobójczej wojny między oboma krajami. Ma on tutaj na myśli II wojnę światową. Porównaj: A. Dugin, Основы геополитики, [w:] źródło elektroniczne: www.arctogaia.ru (08.10.2013).

14 Ibidem, [w:] źródło elektroniczne: www.arctogaia.ru (09.10.2013).

${ }^{15}$ Ibidem, [w:] źródło elektroniczne: www.arctogaia.ru (09.10.2013). 
Odnośnie do Białorusi, Dugin postuluje przyłączenie jej do imperium eurazjatyckiego. Uzasadnia to bliskością kulturową i językową między Rosją a Białorusią. Dla mniejszości etnicznych o odmiennej kulturze, nieodpowiadającej eurazjatyckiemu modelowi, ideolog, dopuszcza utworzenie specjalnych stref administracyjnych o szczególnym statusie, dla ludności wyznania katolickiego i grekokatolickiego.

Szczególnymi kwestiami w geopolitycznych planach ideologa eurazjatyzmu Aleksandra Dugina pozostają sprawa Polski i Ukrainy. Dane kwestie powinny być rozwiązane na korzyść przyszłego imperium eurazjatyckiego przy współpracy Niemiec i Rosji ${ }^{16}$. Polska bowiem, jak twierdzi eurazjata, była częścią tzw. kordonu sanitarnego, będącego częścią polityki Zachodu, stanowił on przeszkodę dla ekspansji Rosji i jej współpracy z Niemcami ${ }^{17}$. Podobnie jak Czechy i pozostałe kraje nieprawosławne Europy Środkowowschodniej, Polska zostanie włączona w strefę wpływów Niemiec. Warto przy tym dodać, iż jednym z wywiadów Dugin stwierdził wprost:

Rosja w swoim geopolitycznym oraz sakralno-geograficznym rozwoju nie jest zainteresowana $\mathrm{w}$ istnieniu niepodległego państwa polskiego w żadnej formie. Nie jest też zainteresowana istnieniem Ukrainy. Nie dlatego, że nie lubimy Polaków czy Ukraińców, ale dlatego, że takie są prawa geografii sakralnej i geopolityki18.

Zdaniem ideologa eurazjatyzmu, Polska jest usytuowana na granicy między katolicyzmem a prawosławiem. Sama jej kultura pozostaje w stanie napięcia czy wręcz konfliktu między katolicyzmem, a tradycją przedchrześcijańską o charakterze słowiańskim. W konsekwencji, jak podsumowuje ideolog, Polska nie jest $\mathrm{w}$ stanie $\mathrm{w}$ pełni zintegrować się ani z Zachodem, ani ze Wschodem. W pierwszym przypadku porozumienie uniemożliwia jej, według określenia eurazjaty, własna słowiańskość obecna $\mathrm{w}$ archetypach, języku, $\mathrm{w}$ drugim zaś przypadku przeszkodą jest katolicyzm Polski. Jak podkreśla Dugin, Polska przez swoje położenie będzie nieustannie narażona na działanie siły zewnętrznej, obecnie ową

16 Aleksander Dugin tak bardzo podkreśla konieczność współpracy niemiecko-rosyjskiej, że nie waha się z uznaniem wypowiadać o pakcie Ribbentrop-Mołotow w wywiadzie dla prawicowego magazynu „Fronda” stwierdził wprost:

Niemcy zaprzepaścili swoją szansę podczas wojny. Trzeba było razem z nami walczyć przeciwko Anglii, obrócić pakt Ribbentrop-Mołotow na Zachód, a wtedy Hitler-Stalin forever. Dziś, zamiast po angielsku, wszędzie by mówiono po rosyjsku i niemiecku. Niemcy na to nie poszli i przegrali. Teraz panuje tam okupacja amerykańska i taki „zamordyzm”, że nawet ust nie można otworzyć.

G. Górny, Czekam na Iwana Groźnego. Wywiad z Aleksandrem Duginem, „Fronda” 1998, nr 11-12, s. 30 .

17 Chodzi o tzw. kordon sanitarny opracowany przez dyplomację francuską w czasie wojny domowej w Rosji.

18 G. Górny, op. cit., s. 30. 
siłą jest Zachód. Inną konsekwencją położenia Polski na mapie Europy, jest niemożność stworzenia stanu pośredniego między Zachodem a Wschodem, a zatem w dziejach Polski nieustannie będzie przewijała się kwestia rozbiorów. Według ideologa, niemożliwy jest stan pośredni między Zachodem a Wschodem, tego typu stan jest bowiem bardzo nietrwały. Jako przykład, eurazjata podaje los I Rzeczpospolitej, która według niego nie była w stanie wybrać między Wschodem a Zachodem i w konsekwencji jej upadek był nieuchronny. W ujęciu eurazjatyzmu, Polska stoi przed wyborem albo tożsamość katolicka albo słowiańska tożsamość. W przypadku odmowy podjęcia decyzji, Polska będzie miejscem konfliktu. Dla Dugina jest oczywiste, iż Polska powinna wybrać przymierze ze Wschodem, czyli przyszłym imperium eurazjatyckim, będzie miała bowiem możliwość postępowania zgodnie ze swoją słowiańską tożsamością.

W celu dokonania wyboru opcji proeurazjatyckiej, konieczne jest sprzyjanie wszelkim działaniom antykatolickim. Według Dugina katolicyzm jest główną przeszkodą w wyborze orientacji eurazjatyckiej. Zaleca stopniowe osłabianie katolicyzmu drogą wspierania polskiej masonerii i ruchów świeckich oraz wzmacnianie innych prądów przeciwnych katolicyzmowi.

Co ciekawe, jako najbardziej interesujące elementy w polskiej historii, Dugin wymienia kulturę mniejszości żydowskiej, polskich masonów i okultystów. Jako najbardziej godnych uwagi w historii Polski Dugin podaje m.in. nazwiska Feliksa Dzierżyńskiego i Jana Potockiego ponieważ: „Oni wszyscy wybrali drogę eurazjatycką"19.

Ideolog eurazjatyzmu zajmuje bardziej radykalne stanowisko względem państwa ukraińskiego, aniżeli polskiego, nie ukrywając, iż zachodzi konieczność rozbioru Ukrainy. Według niego, niemożliwy jest byt polityczny Ukrainy, stanowi ona bowiem wielkie zagrożenie dla interesów Rosji. Zdaniem Dugina samo istnienie Ukrainy jako niezależnego państwa, jest niczym innym jak wypowiedzeniem wojny Rosji na poziomie geopolitycznym ${ }^{20}$. W przekonaniu Dugina, Ukraina staje się narzędziem w rękach cywilizacji Morza i pełni funkcję części ",kordonu sanitarnego" wspomnianego wyżej, w konsekwencji jej istnienie jest samo w sobie zagrożeniem dla Eurazji, dlatego zachodzi konieczność rozbioru Ukrainy.

Aleksander Dugin, omawiając plan podziału Ukrainy, zwraca uwagę na odmienności kulturowe poszczególnych regionów Ukrainy, które determinują $\mathrm{w}$ większym bądź mniejszym stopniu przynależność tych regionów do przestrzeni eurazjatyckiej.

Swoją analizę projektu rozpoczyna od wschodnich obszarów Ukrainy. Biorąc pod uwagę wysoki stopień uprzemysłowienia wschodniej

19 Ibidem.

${ }^{20}$ A. Dugin, Основы геополитики, [w:] źródło elektroniczne: www.arctogaia.ru (14.10.2013). 
Ukrainy i przewagę języka rosyjskiego, możliwe jest nadanie jej szerokiej autonomii, ale jednocześnie dany obszar musi pozostać w sojuszu z Moskwą. Identyczny status będzie posiadać centralna część Ukrainy z miastami Kijów oraz Odessą, razem z obszarem Besarabii.

W stosunku do półwyspu krymskiego, Dugin zwraca uwagę na duży stopień różnorodności etnicznej ludności półwyspu, co może być przyczyną wystąpienia w przyszłości konfliktów, jakie mogą zagrozić stabilności Eurazji. Terytorium półwyspu zamieszkują trzy narodowości: Rosjanie, Ukraińcy i Tatarzy krymscy. Jak przekonuje Dugin, niemożliwe jest spełnienie żądań poszczególnych narodowości, będzie to bowiem niekorzystne dla interesów Imperium Eurazjatyckiego, inaczej nierealne jest bezpośrednie przyłączenie Krymu do Rosji czy zachowanie półwyspu w granicach państwa ukraińskiego, ani też nie jest możliwe przyjęcie geopolitycznej orientacji Tatarów, jest ona bowiem skoncentrowana na Turcji - państwie geopolitycznie wrogim Rosji. Jedynym możliwym rozwiązaniem jest nadanie Krymowi statusu autonomii o specjalnych prawach, jednakże pod kontrolą Moskwy.

Eurazjata traktuje osobno zachodnie regiony Ukrainy, Wołyń, Galicję i Zakarpacie. Wyróżniają się one tym, iż w znacznie większym stopniu jest tu używany język ukraiński, aniżeli rosyjski, a także, jak podkreśla Dugin: „podtrzymuje się antyrosyjską i prozachodnią orientację"21 oraz wyróżniają się odmienną kulturą i wyznaniem ${ }^{22}$, w konsekwencji należy je oddzielić (w tekście oryginalnym - oderwać) od pozostałych obszarów Ukrainy i przyznać specjalny status, a nawet polityczną samodzielność. W dalszej części swojej analizy kwestii ukraińskiej, eurazjata, pomimo iż w przypadku zachodnich obwodów Ukrainy, dopuszcza możliwość przyznania im politycznej niezależności, to podkreśla, iż Rosja powinna występować z inicjatywą uformowania nowej mapy politycznej Europy Środkowowschodniej i sprzyjać rosyjsko-europejskiej współpracy wojskowej przeciwko cywilizacji Morza.

Ideolog, w swoich publikacjach na temat Ukrainy, stale podkreśla nieuchronność jej rozpadu, w wyniku którego pewien obszar jej terytorium zostanie przyłączony do Rosji. Tego typu publikacje ${ }^{23}$ skutkowały tym, iż kilka lat temu władze ukraińskie nie wyraziły zgody na pobyt filozofa na terytorium państwa ukraińskiego.

Aleksander Dugin proponuje bardzo radykalne zmiany w układzie politycznym Europy Środkowowschodniej. Pomimo niewątpliwego roz-

${ }^{21}$ Ibidem, [w:] źródło elektroniczne: www.arctogaia.ru (15.10.2013).

${ }^{22}$ Co ciekawe, z niewiadomych przyczyn Aleksander Dugin, twierdzi, iż na Wołyniu dominującym wyznaniem jest katolicyzm i grekokatolicyzm. Porównaj: A. Dugin, Основы геополитики, [w:] źródło elektroniczne: www.arctogaia.ru (15.10.2013).

${ }^{23}$ Dostępne są na stronie www.evrazia.info (15.10.2013). 
machu jego koncepcja została uzasadniona w sposób powierzchowny, jedynie w oparciu o czynniki kulturowe i religijne. Niekiedy filozof gubi się w próbach określania wyznaniowej przynależności danego obszaru, szczególnym tego przykładem jest Wołyń. Dugin pomija tak ważne $\mathrm{w}$ stosunkach międzynarodowych i w polityce zagadnienia jak: realizm polityczny, kwestie gospodarcze i finansowe oraz poszanowanie integralności terytorialnej danego państwa, nie liczy się z podmiotowością organizacji międzynarodowych. Nie próbuje nawet zastanowić się jakie mogą być konsekwencje na arenie międzynarodowej realizacji takiej inicjatywy reorganizacji struktury politycznej Europy wschodniej, we współpracy z Niemcami.

Można wręcz zadać pytanie jakie możliwości przewiduje Dugin w przypadku, jeśli państwa środkowoeuropejskie i skandynawskie oraz bałkańskie nie wyrażą chęci podporządkowania się Niemcom i Rosji? Nie przytacza nawet powodów, dla jakich dane państwa miałyby się stać krajami podrzędnymi w stosunku do Rosji i Niemiec. Jedyne, co Dugin im oferuje, to bliżej niesprecyzowana autonomia kulturowa, wcale nie przedstawia korzyści politycznych i ekonomicznych, z jakich dane państwa mogłyby skorzystać. Eurazjata nie wyjaśnia również powodów dlaczego $\mathrm{w}$ taki, a nie $\mathrm{w}$ inny sposób należy traktować państwa regionu środkowoeuropejskiego. Z niewiadomych przyczyn, Dugin ujmuje istotę konfliktu międzynarodowego w ramach konfliktu między Lądem a Wodą. Koncepcja ideologa eurazjatyzmu, nie bierze pod uwagę wielu innych istotnych czynników występujących w stosunkach międzynarodowych.

Analiza stosunków międzynarodowych dokonana przez Aleksandra Dugina wykracza poza tradycyjne rozumienie danego zagadnienia, filozof bowiem dopuszcza do dyskursu elementy religijne, wręcz eschatologiczne, zgadza się z koncepcją Samuela Huntingtona o możliwym konflikcie cywilizacji. Dugin przyznaje, że najbliższe jest mu pojmowanie Zachodu jako wcielenia biblijnego Antychrysta ${ }^{24}$.

Odnośnie do aktualnej na dzień dzisiejszy kwestii możliwej przynależności Ukrainy do Eurazjatyckiego Związku Celnego, filozof podkreśla, iż konieczna jest obecność państwa ukraińskiego $\mathrm{w}$ danym podmiocie gospodarczym, bez Kijowa bowiem nie jest możliwe stworzenie trwałej struktury geopolitycznej ${ }^{25}$.

${ }^{24}$ G. Górny, op. cit., s. 30.

${ }^{25}$ Identycznie pojmowano funkcję Ukrainy w politycznej konstrukcji Związku Radzieckiego. Porównaj: W. Marciniak, Rozgrabione imperium. Upadek Zwiazku Radzieckiego i powstanie Federacji Rosyjskiej, Kraków 2001. Sam pomysł utworzenia Związku celnego zaproponowanego przez Władimira Putina Dugin przyjął z aprobatą, ale nie jest to jeszcze w pełni zrealizowany projekt eurazjatycki, jaki opracował Dugin. 
Aleksander Dugin, rozważając znaczenie krajów współczesnego Zachodu, z niewiadomych powodów przypisuje im totalitarną homogenizację $^{26}$ niekiedy stanowczo wyolbrzymia możliwości militarne jedynego na świecie supermocarstwa. Niemniej, jego zdaniem, współczesna Rosja poprzez popieranie systemu wielobiegunowego ogranicza hegemonię Ameryki27.

Aleksander Dugin ma wyróżniającą się pozycję wśród rosyjskich intelektualistów. Według Romana Backera jest on najbardziej oryginalnym współczesnym rosyjskim myślicielem, ale jednocześnie jego sposób myślenia jest jednym $\mathrm{z}$ najbardziej irracjonalnych, metafizycznych i w pełni przynależnych do logiki emanatystycznej28. Współczesny eurazjatyzm na obecnym etapie pozostaje jedynie marginalnym prądem filozoficznym.

26 R. Backer, Rosyjskie myślenie polityczne za czasów prezydenta Putina, Toruń 2007, s. 198.

27 Więcej na ten temat: A. Bryc, Rosja w XXI wieku. Gracz światowy czy koniec gry?, Warszawa 2009. Warto dodać, iż sam Zbigniew Brzeziński, tak bardzo znienawidzony przez Dugina, stwierdza, iż Ameryka jest niewątpliwie potęga, jednakże jej zakres hegemonii jest płytki, a biorąc pod uwagę ogromne zróżnicowanie i wielkość Eurazji, zasięg oddziaływania jest ograniczany. Porównaj: Z. Brzeziński, Wielka szachownica. Główne cele polityki amerykańskiej, Warszawa 1998, s. 42.

28 R. Backer, Rosyjskie myślenie za czasów prezydenta Putina, Torun 2009, s. 202. 